\title{
LOGIŠKUMAS KALBOJE IR MĄSTYME ${ }^{1}$
}

\author{
Virginija Jakimenko \\ Mykolo Romerio universiteto \\ Filosofijos ir humanistikos institutas \\ Ateities g. 20, LT-08303 Vilnius, Lietuva \\ Telefonas (+370 5) 2714628 \\ El. paštas:vijak@mruni.eu
}

Pateikta 2014 m. liepos 1 d., parengta spausdinti 2014 m. gruodžio 14 d.

doi:10.13165/SMS-14-6-3-03

Anotacija. Logiškumas yra su mąstymu ir kalba siejama tradicinè vertybé, kurios svarba mokslinio pažinimo sferoje nekelia abejonių. Tarpdisciplininiu moksliniu tyrimu epochoje, kai kognityviniai mokslai (cognitive sciences) supina ir vienija filosofu, psichologu, neurologu, lingvistu, antropologu, biochemiku ir dirbtinio intelekto specialistu pastangas bei ižzalgas apie mąstyma ir pažinima, logiškumo reikšmingumas auga. Ilgai manyta, kad pagal logikos taisykles funkcionuoja ir kalba, kuria bendraujame, kadangi jos pagrindas yra gramatikos taisykles. Bet gramatine forma yra nepatikimas orientyras, nes ji vienareikšmiškai nerodo, kaip vartojamas šis konkretus sakinys. Kalbos vaidmuo mąstymo procese vis dar diskusiju objektas, nes mąstymo ryšys su kalba ir kalbèjimu yra labai sudètingas. Tiesiogiai stebèti minties tapimo žodžiais momento mes negalime bei nežinome, kodèl kai kuriuos žodžius galime vartoti tiek tiesiogine, tiek ir perkeltine prasme arba kodèl sudarytos iš tu pačiu žodžiu kalbinès konstrukcijos yra subtiliai skirtingos. Kita vertus, kalba yra be galo svarbus mastymo

1 Mokslinis tyrimas finansuojamas Europos socialinio fondo lěšomis pagal visuotinès dotacijos priemonę.

Socialinių mokslų studijos / Societal Studies

(C) Mykolo Romerio universitetas, 2014

(C) Mykolas Romeris University, 2014
ISSN 2029-2244 (online)

http://www.mruni.eu/lt/mokslo_darbai/SMS/

http://www.mruni.eu/en/mokslo_darbai/SMS/ 
dèmuo, todèl tiriant kalbèjimo kitima gali būti fiksuojami ir mąstymo, taip pat ir atsirandantys dèl ilgalaikio informaciniu technologiju vartojimo, pokyčiai. Bet diskusijos dèl informaciniu technologiju vartojimo ir ju poveikio mąstymui turi savo ypatumų.

Reikšminiai žodžiai: mąstymas, logiškumas, loginis ir kalbinis mąstymo lygmenys, informacinès technologijos, mąstymo pokyčiai.

\section{Ivadas}

Mąstymas nèra tik fiziologinis procesas, bet jis nẻra ir nieko bendro su fiziniu pasauliu neturintis vyksmas. Socialiniai, humanitariniai ir gamtos mokslai tiria mąstymą skirtingais aspektais, nes mąstymas yra ir socialinis procesas (gyvenimas tarp žmonių yra būtina sąlyga vaikui išmokti mąstyti), ir verbalinis procesas (savo mintis fiksuojame ir mąstymo išvadą išreiškiame kalbos priemonèmis), ir fiziologinis procesas (juk sveikos žmogaus smegenys yra būtina mąstymo / kalbejjimo sąlyga). Kiekvienas mokslas supranta tyrimo objekto svarbą ir taiko savo metodus bei technologijas. Logikos mokslas tiria kalba išreikšta mastyma ir formuluoja kriterijus bei metodus žmogaus minčių ryšio stiprumui ịvertinti. Kita vertus, mūsų minties tikslumą gali garantuoti tik kalbos, kuria fiksuojame mintị, tikslumas, o žodžiais neišreikštos mintys yra prarandamos amžinai. Tačiau kalba nẻra vien tik priemonė mintims reikšti. Kalbų labai daug, o kiekviena kalba yra ne tik nepakartojama garsų, gramatikos ir žodyno sistema, bet taip pat ir svarbus bendruomenès tapatybės rodiklis bei unikalus žinių apie žmonių gyvenimą šaltinis. Glaudus kalbos ir mąstymo ryšys yra pakankamas pagrindas prielaidai, jog kai kurie kalbos / kalbejjimo kitimai yra mąstymo kitimo rodikliai. Kalbininkai, nuolat stebėdami natūralų kalbos kitimą, fiksuoja ir mąstymo pokyčių požymius. Pavyzdžiui, abejingumas minties išraiškos tikslumui yra aprašomas taip: „Viešosios kalbos stebėsena rodo, kad dabar linkstama nusitverti vieną ar kitą žodị, visiškai negalvojant, ar jis tinka ar netinka. Taip elgiamasi ir su lietuviškais, ir su tarptautiniais žodžiais bei kitais skoliniais. Šitaip geri, taisyklingi žodžiai stilistiškai nuvalkiojami, kiti retai vartojami ịprasti mūsų kalbai žodžiai pamirštami. Kita vertus, daugelis taisyklingų žodžių vartojami ne vietoje, ne savo reikšme. Taigi, neparenkamas tikslesnis žodis norimai minčiai pasakyti, ji temdoma. “2 Bet gal netiksli kalba reiškia kažką daugiau nei vien ribotą žodžių atsargą?

Kalbos vaidmuo mąstymo procese vis dar tebèra mokslininkų ir filosofų diskusijų objektas, nes mąstymo ryšys su kalba ir kalbejjimu yra labai sudètingas. Mes negalime tiesiogiai stebèti minties tapimo žodžiais momento, mes nežinome, kodèl kai kuriuos žodžius galime vartoti tiek tiesiogine, tiek ir perkeltine prasme, kodèl sudarytos iš tų pačių žodžių kalbinès konstrukcijos yra subtiliai skirtingos ${ }^{3}$, kodèl gramatinè

2 Rudaitienè, V. Raskime žodžiui vietą. Gimtoji kalba. 559, p. 4.

3 Pinker, S. The Stuff of Thought. Language as a Window into Human Nature. Penguin books, 2007. 
forma nerodo, kaip yra vartojamas šis konkretus sakinys ir dar daugybės kitų dalykų. Bet kalba yra be galo svarbus mąstymo dèmuo, todèl ir mąstymo pokyčiai gali būti fiksuojami tiriant kalbejjimo kitimą. Todèl netiksli kalba gali rodyti ir mąstymo paviršutiniškumą, kurio priežastis - informacijos gausa.

\section{Logiškumo vertybė}

Logiškumu priimta vadinti gebejjimą mąstyti (protauti) ir kalbėti (rašyti) aiškiai, nuosekliai, neprieštaringai ir pagrịstai. Ši savybè visais laikais laikyta vertybe. Vertybès yra stiprios vidinès nuostatos, darančios ịtaką žmonių elgesiui, kuriomis pateisiname ir mūsų tikslus, ir konkrečius veiksmus. Vertybinė orientacija nẻra vien konkretaus asmens charakteristika, nes kiekvienos socialinès grupés ar net tam tikro laikotarpio visuomenès vertybių hierarchija turi tik jai būdingų bruožų. Žmonės perima ir ísisavina vertybes socializacijos procese. Kita vertus, vertybės egzistuoja hierarchijoje, kuri nèra duota kartą visiems laikams, ir, pasikeitus žmonių gyvenimo aplinkybėms, vertybių hierarchija dažnai keičiasi. Su kuo siejama ši vertybė? Žodynai pateikia daugybę logiškumo sinonimų: nuoseklumas, ryšys, sąryšis, darna, protingumas, neatsitiktinumas, neprieštaringumas, pagrịstumas, dèsningumas, dèsnis, logika ir t. t. Logiškumo sampratų yra daug, bet teoriniu lygmeniu šis terminas vartojamas žodžių junginiuose: „mąstymo logiškumas“, „kalbos logiškumas“ ir „veiksmų logiškumas". Veiksmų (elgesio) logiškumas neturi specifinių kriterijų ir reiškia daugiau elgesio racionalumo lygio įvertinimą, o kalbos logiškumas yra gana sudètinga žmonių komunikacijos kokybès charakteristika, kuri apibūdinama kaip sugebejjimas nuosekliai, neprieštaringai bei argumentuotai žodžiais reikšti mintis, nepažeidžiant jokių gramatikos taisyklių. Literatūroje minimi kalbos logiškumo kriterijai (apibrèžtumas, nuoseklumas, pagrịstumas ir neprieštaringumas) apeliuoja ị pagrindinius logikos dèsnius (tapatybès, prieštaravimo, negalimo trečiojo ir pakankamo pagrindo). Bet lingvistine šio logiškumo sąlyga laikomas taisyklingas kalbos elementų derinimas visais lygiais: tikslus žodžiu ir žodžių junginių vartojimas pagal jų reikšmes bei tinkami žodžių ryšiai frazių, sakinių ir teksto lygmenyse. Kalbos logiškumas ir tikslumas yra glaudžiai susiję charakteristikos, kurias atskirti nelengva, nes ir kalbos tikslumas, ir logiškumas yra formuluojami tikrovès-mąstymo-kalbos-kalbejjimo ryšio pagrindu. Tik kalbos tikslumu yra vadinamas atitikimas to, kas pasakyta, tam, kas norèta pasakyti, o kalbos logiškumas apibūdina kalbos struktūrą ir kalbos vienetų prasminius ryšius. Vadinasi, netikslus kalbejjimas gali būti tiek nepakankamo kalbos mokèjimo, tiek ir prieštaringo mąstymo pasekmè.

Mąstymo logiškumas yra tai, ko ieškome vartojamoje kalboje ir žmonių veiksmuose. Jo esmè - stiprus kalba išreikštų minčių ryšys, leidžiantis pasikliauti padarytomis išvadomis (mąstymo rezultatais). Minčių tarpusavio ryšius nagrinèja logikos mokslas, kuris bendroje mokslų klasifikacijos sistemoje įrašytas kaip filosofinè logika (humanitariniai mokslai, H140) bei matematinè logika (P110) ir dirbtinis intelektas (P176), kurie priskiriami fizinių mokslų sričiai. Tačiau kiek logika yra filosofija 
(filosofijos dalis)? Anot J. M. Bochenski, išlikusiuose Aristotelio darbuose ši problema nèra specialiai aiškinama, nors Aristotelis tikrai stengèsi suformuluoti pagrindines logikos sąvokas neutraliai, nesiedamas jų su jokia konkrečia filosofine orientacija, nes Aristotelis nelaikè logikos filosofijos dalimi, o greičiau priemone / ịrankiu, skirtu tiek filosofams, tiek ir mokslininkams ${ }^{4}$. Kita vertus, J. Lukasievič (1937) rašè, kad „logika buvo laikoma filosofijos dalimi labai ilgai, bet šiuolaikinè formalioji logika yra tiek nutolusi nuo filosofijos, kad ją reikia traktuoti kaip savarankišką mokslą, kuris nèra nei filosofija, nei filosofijos dalis ir nèra susijęs su jokia filosofijos kryptimi net ir netiesiogiai. Pagrindinis logikos uždavinys - taisyklingų išvedimo ir ịrodymo būdų nustatymas, taigi, tas pats uždavinys, kurị sprende Aristotelis, kurdamas savo silogizmo teoriją ${ }^{5}$. Tačiau ar toks logikos tapatinimas su formaliąja logika yra pateisinamas? Ar taip neprarandama dalis labai svarbios moksliniam pažinimui šio mokslo problematikos? Paulo Thagardo nuomone, „terminas „logika“ pradètas vartoti „formalios logikos" prasme Fregès ir Russelo tradicijoje, kas kontrastuoja su ankstesniąja platesne logikos kaip protavimo mokslo ir meno samprata“6. Išties J. S. Millio „Logikos sistemoje" (1843) aptariami mentaliniai mokslinio pažinimo aspektai (priežastinių ryšių nustatymo metodai), o Č. Pirso abdukcija irgi yra sudetingas giluminis psichologinis procesas. Todèl šiuolaikinè natūralistinè epistemologija atsisako psichologijos pašalinimo iš filosofijos metodo, nors kai kurie filosofai (H. Reichenbach, K. R. Popper ir kt.) pabrèžia logikos ir psichologijos skirtingumą, kuris, anot Thagardo, „yra rezultatas filosofijos ir psichologijos shizmos, ivykusios Fregei ir Huserliui atsisakius psichologiškumo filosofijoje dèl jo priešiškumo pažinimo objektyvumui “7 . Logikos ir logiškumo vaidmuo pažinimo procese tikrai yra ypatingas: būti naujų žinių patikrinimo ir „iteisinimo“ priemone. Todèl mokslinis pažinimas be logiškumo kriterijaus neįsivaizduojamas ir tai kontrastuoja su kasdieniniu gyvenimu, kur dažnam pakanka vien sukauptos patirties. Mokslinis pažinimas yra ta sritis, kur spèliojimas ir „gražus“ kalbejjimas nèra vertybè, nes čia kiekviena išvada laikoma teisinga, tik jei ji yra pagrịsta. Kad ir kas bebūtų mokslinio pažinimo objektas konkrečiu atveju, jị tiriant privalu samprotauti nepažeidžiant logikos taisyklių. Tik nemokslininkai ịsivaizduoja mokslo vystymąsi kaip nuoseklų judejimą nuo suformuluotų hipotezių prie jų îrody-

4 Bochenski, J. M. History of formal logic. University of Notre Dame Press, 1961, p. 44-45. „Aristotle knew well enough what he demanded of logic...Aristotle is looking for relations of dependence and in that connection makes a sharp distinction between the validity of this relation and the kind of premises, or their truth. The text contains what is historically the first formulation of the concept of formal logic, universally valid and independent of subject matter."

5 Lukasievic, J. W obronie logistyki. J. Łukasiewicz. Z zagadnień logiki i filozofii. Pisma wybrane. [interaktyvus]. PWN. Warszawa, 1961[žiūrèta 2014-05-05]. <http://www.philosophy.ru/library/lukasiewicz/apologist.html>.

6 Thagard, P. The Cognitive Science of Science. Explanation, Discovery and Conceptual Change. The MIT Press Cambridge, Massachusetts, 2012, p. 182.

Ibid., p. 183. 
mo arba atmetimo (kai prieštarauja empiriniams duomenims). O tikrovejje hipotezès neatitinka turimų empirinių duomenų ir visokių paradoksų pasitaiko. Juk hipotezė nèra būtinas turimo žinojimo sekmuo. Bet jei naujos žinios nèra logiškai išvedamos iš jau turimų, o gaunamos loginio „šuolio“ mąstyme dèka (abdukcija, analogija, indukcija), vadinasi, jos gali ir turi būti pagrịstos kitaip. Taip kiekvienam išvedimo būdui skiriamas savas vaidmuo pažinime, o logika tarsi sudeda savo „filtrus“ (pagrịstumo, ịrodymo griežtumo), kurių tikslas - išaiškinti galimus prieštaravimus (nelogiškumus). Kita vertus, tai ne duokle tradicijai, nes taip reguliuojama mokslinè veikla ir saugomasi nekritiško patikejjimo neaiškiomis intuicijomis / prietarais / nuomonèmis. Logika tiria ịrodymų griežtumą, o logiškumas reikalauja teiginio tikslumo, apibrèžimo aiškumo ir išvedimo validumo, todèl tarpdisciplininių mokslinių tyrimų epochoje, kai kognityviniai mokslai (angl. cognitive sciences) supina ir vienija filosofų, psichologų, neurologų, lingvistų, antropologų, biochemikų ir dirbtinio intelekto specialistų pastangas bei ị̌zvalgas apie mąstymą ir pažinimą, logiškumo vertybė mokslinio pažinimo sferoje lieka savo pozicijose. O kaip atrodo kasdienybė?

\section{Informacinès technologijos ir mąstymas}

Stebina, kai aukštųjų mokyklų studentai (geriausia jaunosios kartos dalis) netiksliai vartoja ir žodžius, ir sąvokas. Ar tik dẻl nežinojimo? Vidurinè mokykla nuolat reformuojama, gal todèl ị aukštąsias mokyklas ateina neparengti studentai, kurie daro elementarias gramatines klaidas ir vengia galvoti (protauti, išvesti atsakymą), bet iškart puola „guglinti“, nẻ nebandydami kitaip ieškoti atsakymo. O gal jie tiesiog kitaip pasirengę ir kitaip mąsto? Paskaitos metu į klausimą auditorijai pirmasis atsako ne tas studentas, kuris savarankiškai samprotauja, o dažniau tas, kuris greičiau pasinaudojo informacijos paieška. Taip informacinių technologijų vartojimo igūdžiai „išstumia“ senąji būdą ieškoti atsakymo: protavimą. Tačiau daugiau nerimo kelia jų požiūris ị informacines technologijas: anksčiau paieška internete tebuvo patogus ivvairios informacijos šaltinis, o dabartiniai aštuoniolikmečiai visai nekritiškai pasitiki informacinėmis technologijomis ir net daugiau. Pavyzdžiui, logikos seminare dvieju skirtingų akademinių grupių studentai (iš penkių Teisès fakulteto grupių) piktinosi, kodèl "google“ nèra dedukcijos uždavinio sprendimo. Tikriausiai ankstesniųjų metų studentai irgi ieškojo dedukcijos uždavinių sprendimo internete, tik savo nusivylimo jie viešai nerodè. Ar tai, kas vyksta, yra požymis to „visuomenès aptingimo“, apie kurị gimnazijos direktorè kalbèjo žiniasklaidai ${ }^{8}$. Vargu ar atsakymai ị visus kitus klausimus jau yra "google“, bet po kelių metų, matyt, ten bus ir to dedukcijos uždavinio sprendimas. O juk toks požiūris atsiliepia jaunų žmonių mąstymui? Juk informacijos ieškojimas nèra protavimas ar uždavinio sprendimas, nes atliekami visai kiti veiksmai. 
Ilgalaikio informacinių technologijų vartojimo poveikis žmonių mąstymui bei elgesiui domina ir specialistus, ir nespecialistus ${ }^{9}$. Specialistai ypač pabrèžia informacinių technologijų ịtaką vaikų vaizduotei, jų erdvės suvokimui, pastabumui, žodiniam kūrybingumui ir kitiems sugebejjimams ${ }^{10}$. Dèl naujųjų informacinių technologijų poveikio specifikos vaikai nebelavina atminties ir jiems nebereikia užrašų, nes informaciją galima bet kada susirasti. Jie tiki viskuo, ką rodo televizorius arba kompiuteris, nes nemato tikrosios gamtos, daug laiko praleidžia virtualioje tikroveje, todèl netenka bendravimo tikrovèje igūdžių, praranda subtilumo pajautimą, bet mainais igyja kitų galių. Jie sugeba ịspèti teisingą testo atsakymą pagal kalbinius požymius, jie be ypatingų pastangų naudoja iškart dvi technologijas (arba daugiau), vienu metu atlieka daug darbų, nors dèl to ir pasitaiko daugiau klaidų. Kadangi žmogaus prigimtis visada ieškoti būdų pasiekti tikslą mažiausiomis energijos sąnaudomis - tai kam mokytis, jei galima „paguglinti“, ypač kai žaidimai įskiepijo algoritmą „bandyk dar kartą ir pavyks". Kita vertus, studentai įmesti ị situaciją, kurią sukūrẻ šiuolaikiné visuomenè. Jos esmė atsiskleidžia atlikus paiešką pagal bet kurị raktažodị, nes tuomet iškart matome, kokia informacija pateikiama pirmiau. O kai informaciją gauti yra lengva, tai problemiška tampa atsirinkti ją. Čia jau būtini kritiško mąstymo ịgūdžiai, kurie formuojasi mokantis logikos ir filosofijos. Taigi, visuomenès mąstymą galima paveikti per studijų programas, bet jei tai nedaroma, tai ko stebètis, kad ̨̇vaizdis tampa bene svarbesnis už esmę, kad žmonès tenkina mitai vietoj žinių, kad kūno kalba komunikacijoje išstumia žodžius, o protavimą pakeičia informacijos paieška internete.

Informacinès technologijos yra vertinamos skirtingai. Vieni autoriai mato jose potencialią grèsmę mūsų mąstymui, atminčiai ${ }^{11}$ ar net mūsų smegenų struktūrai, o

9 Taylor, J. How Technology is Changing the Way Children Think and Focus [interaktyvus]. [žiūrèta 2014-05-05]. <http://www.psychologytoday.com/blog/the-power-prime/201212/how-technology-is-changing-the-way-children-think-and-focus $>$.

Douglas, K. Will technology replace thinking? [interaktyvus]. [žiūrèta 2014-05-05]. <http:// www.huffingtonpost.com/kirk-douglas/will-technology-replace-t_b_4039525.html>.

10 Saukienè, I., supra note 7.

Priklausomų nuo interneto asmenų smegenys panašios ị sergančių alkoholizmu [interaktyvus]. ELTA [žiūrèta 2014-05-05]. <http://www.delfi.lt/news/daily/health/priklausomu-nuo-interneto-asmenu-smegenys-panasios-i-serganciu-alkoholizmu.d?id=54092489>.

Kaip internetas keičia mūsų mąstymą [interaktyvus]. [žiūrèta 2014-05-05]. <http://valstietis. balsas.lt/Pradzia/Naujienos/Technologijos/Kaip-internetas-keicia-musu-mastyma> .

11 "My mind isn't going - so far as I can tell-but it's changing. I'm not thinking the way I used to think. I can feel it most strongly when I'm reading. Immersing myself in a book or a lengthy article used to be easy. My mind would get caught up in the narrative or the turns of the argument, and I'd spend hours strolling through long stretches of prose. That's rarely the case anymore. Now my concentration often starts to drift after two or three pages. I get fidgety, lose the thread, begin looking for something else to do. I feel as if I'm always dragging my wayward brain back to the text. The deep reading that used to come naturally has become a struggle." Carr, N. G. Is Google Making Us Stupid. The Atlantic [interaktyvus]. 2008, 301(6) [žiūrèta 201405-05]. <http://www.theatlantic.com/magazine/archive/2008/07/is-google-making-us-stupid/ $306868 />$. 
kiti, priešingai, puikias perspektyvas, nes informacinès technologijos - tai žmogaus smegenų pratęsimas, žmonių sukurtas sprendimas supersudètingoms užduotims ${ }^{12}$. Šių dienų mokslas neịsivaizduojamas be naujausių duomenų apdorojimo technologijų, tačiau technologijos taip pat yra būtinas mokymosi komponentas, kuris leidžia studentams palaipsniui (nuo paprastų prie sudetingų dalykų) mokantis padaryti tai, ko jie niekuomet nedare (naudojant duomenų bazes, Youtube, paieškų sistemas). Kaip teigia M. Prensky, XXI amžiuje skaitymas jau nebe pagrindinè mokymosi sąlyga, nes atsirado informacinès technologijos, kurios tai gali atlikti už mus, todèl ar skaitmeninių technologijų laikais verta mokyti studentus rašyti ranka, skaičiuoti mintyse, skaityti ir kt.? Gal tai bus tarsi mokymas medžioti maistui, kuris tikrai buvo labai naudingas, bet tik anksčiau ${ }^{13}$.

Diskusijos dèl informacinių technologijų domina visus jų vartotojus. Viena aktualiausių temų - interneto indèlis ị kultūrą ir ekonomiką. Literatūros gausoje ir požiūrių i̇vairovèje susivokti padès A. Therier atliktas autorių (knygos, straipsniai, tinklalapiai) skirstymas $\mathfrak{i}$ interneto optimistus ir skeptikus ${ }^{14}$. Jis pripažįsta, kad interneto poveikis kultūrai ir visuomenei greičiau destruktyvus nei vien tik gèrị nešantis, bet save vadina interneto optimistu. Therier pabrèžia, kad interneto skeptikai atskleidè nemažai interneto ardančiojo poveikio elementų, bet jie elgiasi kaip luditai. $\mathrm{O}$ interneto optimistai mato interneto vaidmeni pagražintą ir tiki, kad kolektyvinis intelektas bei masinis bendradarbiavimas atveria naujas galimybes keisti ekonomiką i gerąją pusę, o internetas gali tarnauti ir kaip išlaisvinimo priemonè. Vèlesniame darbe išplètoja ši požiūrị ${ }^{15}$.

Neabejotinas interneto skeptikų lyderis yra Nicholas Carras, talentingas ir žinomas rašytojas, ne vieno bestselerio autorius. Jis teigia, kad technologijų vystymasis veikia žmonijos istorijos eigą. Centralizuota maisto gamyba, vandens tiekimas, transportas, raštas, elektra paveikè formuojančias visuomenę sąlygas. Kompiuterizacija pakeis pramonę (ir ne tik ją) ne mažiau kaip kadaise ją pakeitė elektra, o gal ir labiau. Kompiuterinès programos jau tapo svarbia sudedamąja dalimi ne tik pramonèje ir prekyboje, bet ir kitose gyvenimo srityse. N. Carras teigia, kad, „technologija formuoja ekonomiką, o ekonomika formuoja visuomenę "16. Tai labai sudètingas procesas,

12 Prensky, M. Our Brains Extended. Educational Leadership [interaktyvus]. 2013, 70(6): 22-27 [žiūrèta 2014-05-05]. <http://www.ascd.org/publications/educational-leadership/mar13/vol70/ num06/Our-Brains-Extended.aspx $>$.

13 Ibid.

14 Thierer, A. Grouping Recent Net Books: Internet Optimists vs. Pessimists [interaktyvus]. [žiūrèta 2014-05-05]. <http://techliberation.com/2008/09/06/grouping-recent-net-books-internet-optimists-vs-pessimists/>.

15 Are You An Internet Optimist or Pessimist? The Great Debate over Technology's Impact on Society [interaktyvus]. [žiūrèta 2014-05-05]. <http://techliberation.com/2010/01/31/are-you -an-internet-optimist-or-pessimist-the-great-debate-over-technology's-impact-on-society/>.

16 Carr, N. Is Google Making Us Stupid? [interaktyvus]. [žiūrèta 2014-05-05]. <http://www.theatlantic.com/magazine/archive/2008/07/is-google-making-us-stupid/306868/Carr, <...>. N. The Shallows: What the Internet Is Doing to Our Brains, 2010 
kuriame dalyvauja ekonomika, technologija ir žmogaus prigimtis. „Kaip individai mes galime abejoti arba net priešintis technologijų naudojimui, bet tai bus vienetiniai ir galų gale nenaudingi veiksniai, nes visuomeneje, kurią valdo ekonominiai kompromisai, technologinis imperatyvas yra būtent tai, kas jis yra - imperatyvas. O asmeninis pasirinkimas su tuo neturi nieko bendro. ${ }^{" 17}$ Carro nuomone, technologijos ir ekonomikos sąveika aiškiai matoma, kai kinta visuomenei svarbaus resurso tiekimas (produktas imamas tiekti centralizuotai arba vietiškai). Tai vyksta dabar su informacinèmis technologijomis: pasikeité kompiuterių naudojimo paradigma, nors ir ne iškart. Tam tikros centralizuotos duomenų perdirbimo formos egzistuoja seniai, bet dabar jos keičiasi ir tampa vis galingesnès. Nors dauguma žmonių vis dar priklauso nuo asmeninių kompiuterių, bet vis dažniau naudojami ne vien tik mūsų kompiuteryje esami duomenys ir programos, o programos internetu. Taip mūsų kompiuteriai virsta terminalais, kurių galingumo ir naudingumo šaltinis yra internetas. Carras rašo, kad internetas yra galingų technologijų rinkinys, kurios leistų visiems pajungtiems kompiuteriams dirbti kaip viena mašina. $O$ juk internetas svarbus ne tik darbui ar pomėgiams, bet jis perima daugybę kitų funkcijų, net tampa klausykla, kur žmonès atskleidžia savo nuodèmes, nusikaltimus, ikkyrias idejas ir pan., nes anonimiškumas internete - tik iliuzija, kadangi visa informacija apie tai, ką darome internete (ką žiūrime, skaitome, ko klausiame ir kaip), renkama ir saugoma duomenų bazėse, susieta su asmenybe per naudotojo vardą, kreditinès numerį ar paieškos istoriją ${ }^{18}$.

\section{İžvalgos / išvados}

Informacinès technologijos lengvina žmonių gyvenimą îvairiais požiūriais, tačiau ar pastebime, kaip stipriai ilgalaikis informacinių technologijų vartojimas transformuoja mūsų tikrovès suvokimą, veikia mūsų kalbą ir net pakeičia mūsų mąstymą. Informacinès technologijos ipratina mus prie lengvai gaunamos informacijos gausos, todèl pamažu prarandame sugebẻjimą susikaupti / kontempliuoti, o mūsų mąstymas tampa paviršutiniškas, pamažu kinta jo kriterijai (pavyzdžiui, sprendimo greitis konkuruoja su logiškumu). Šių tendencijų pasekmès yra sunkiai nuspèjamos, todèl logiškumas dabartinèje globalizacijos ir informacinių technologijų epochoje yra būtina vertybè, kaip ir kritiškas mąstymas.

\section{Literatūra}

Bochenski, J. M. History of formal logic.

University of Notre Dame Press, 1961.

Carr, N. G. Is Google Making Us Stupid.

The Atlantic [interaktyvus]. 2008,
301(6) [žiūrèta 2014-05-05]. <http:// www.theatlantic.com/magazine/ archive/2008/07/is-google-making-usstupid/306868/>. 
Carr, N. The Big Switch: Rewiring the world, from Edison to Google.

Carr, N. The Shallows: What the Internet Is Doing to Our Brains. 2010.

Lukasievic, J. W obronie logistyki. J. Łukasiewicz. Z zagadnień logiki i filozofii. Pisma wybrane. PWN. Warszawa [interaktyvus]. 1961 [žiūrèta 201405-05].<http://www.philosophy.ru/ library/lukasiewicz/apologist.html>.

Pinker, S. The Stuff of Thought. Language as a Window into Human Nature. Penguin books, 2007.

Prensky, M. Our Brains Extended. Educational Leadership [interaktyvus]. 2013, 70(6) [žiūrèta 2014-05-05]. <http://www.ascd.org/publications/ educational-leadership/mar13/vol70/ num06/Our-Brains-Extended.aspx>.

Rudaitienè, V. Raskime žodžiui vietą. Gimtoji kalba. 559: 4.

Saukienè, I. Naujujų technologijų visuomene: kaip keičiasi vaiku vaizduotè ir mąstymas [interaktyvus]. [žiūrèta 201405-05]. <www.delfi.lt/archive/article. php?id=57237455>.
Priklausomų nuo interneto asmenų smegenys panašios ị sergančių alkoholizmu. ELTA [interaktyvus]. [žiūrèta 201405-05]. <http://www.delfi.lt/news/daily/ health/ priklausomu-nuo-interneto-asmenu-smegenys-panasios-i-serganciualkoholizmu.d?id=54092489>.

Thagard, P. The Cognitive Science of Science: Explanation, Discovery, and Conceptual Change. Massachusetts Institute of Technology, 2012.

Thierer, A. Grouping Recent Net Books: Internet Optimists vs. Pessimists [interaktyvus]. [žiūrèta 2014-05-05]. $<$ http://techliberation.com/2008/09/06/ grouping-recent-net-books-internetoptimists-vs-pessimists/>.

Thierer, A. Are You An Internet Optimist or Pessimist? The Great Debate over Technology's Impact on Society [interaktyvus]. [žiūrèta 2014-05-05]. <http:// techliberation.com/2010/01/31/areyou-an-internet-optimist-or-pes simistthe-great-debate-over-technology'simpact-on-society/>.

\title{
LOGICALITY IN SPEAKING AND THINKING
}

\author{
Virginija Jakimenko \\ Mykolas Romeris University, Lithuania
}

Summary. Logicality means clear and sound reasoning according to the rules of logic or formal argument. Logicality is a traditional, associated with thinking and speech, value, which has a great importance in the area of scientific discovery. In the era of trans-disciplinary research, cognitive sciences unite the efforts of philosophers, psychologists, neurologists, linguists, anthropologists, biochemists and the artificial intelligence specialists to understand the thinking and cognition, thus increasing the importance of logicality. Perhaps therefore it has been presumed that the speech we use for communication is functioning according to the rules of logic, using the rules of grammar as a base. The speech is a highly important part of thinking, although the actual role it plays in the process of thinking is highly debatable. Since we cannot observe directly the moments when thoughts turn into words, we do not know why the structures of speech 
that consist of the same words can be slightly different or why the same words have both, direct as well as indirect, meanings. The changes in thinking can be observed only via the changes in speech. However, here the factors that influence these changes must be taken into account. One of such factors discussed in this paper is the long term effect of information technologies on human thinking.

Keywords: thinking, logicality of thinking, changes in thinking.

Virginija Jakimenko, Mykolo Romerio universiteto Filosofijos ir humanistikos instituto docentè. Mokslinių tyrimų kryptys: filosofija, logika.

Virginija Jakimenko, Mykolas Romeris University, Institute of Philosophy and Humanities, Associated Professor. Research interests: philosophy, logics. 